\title{
Reopening of dental clinics during SARS- CoV-2 pandemic: an evidence-based review of literature for clinical interventions
}

\author{
Seied Omid Keyhan ${ }^{1,2}$, Hamid Reza Fallahi ${ }^{3}$, Amin Motamedi ${ }^{4}$, Vahid Khoshkam5, Paymon Mehryar ${ }^{6}$, \\ Omid Moghaddas ${ }^{7}$, Behzad Cheshmi ${ }^{8^{*}}$, Parsa Firoozi ${ }^{9}$ D, Parisa Yousefi ${ }^{10}$ and Behzad Houshmand ${ }^{11}$
}

\begin{abstract}
Background: Severe acute respiratory syndrome coronavirus 2 (SARS-CoV-2) causes serious acute respiratory diseases including pneumonia and bronchitis with approximately $2.3 \%$ fatality occurrence.

Main body: This study argues the main concepts that need to be considered for the gradual reopening of dental offices include treatment planning approaches, fundamental elements needed to prevent transmission of SARSCoV-2 virus in dental healthcare settings, personal protection equipment (PPE) for dental health care providers, environmental measures, adjunctive measures, and rapid point of care tests in dental offices.

Conclusion: This article seeks to provide an overview of existing scientific evidence to suggest a guideline for reopening dental offices.
\end{abstract}

Keywords: SARS-CoV-2, COVID-19, Dental clinics, Dentistry

\section{Background and history}

Coronaviruses (CoVs) are the largest group of known positive-sense RNA viruses with a variety of hosts in nature [1]. In the beginning, coronaviruses were thought to cause only enzootic infections in several animals, including a community of birds and mammals. However, current studies have shown that these viruses are infectious in humans $[2,3]$. Seven major coronaviruses (CoVs) were recognized by 2020, including SARS-CoV2. Within these 7 viruses, three of them (SARS-CoV, MERS-CoV, SARS-CoV-2) lead to serious respiratory syndromes with considerable death rates [4-6]. In 2002, SARS-CoV extended over five continents with a $10 \%$ death rate, and in 2012, MERS-CoV emerged with a 35\% fatality rate in the Arabian Peninsula [7]. A novel

\footnotetext{
* Correspondence: Beh.cheshomi@gmail.com

${ }^{8}$ Faculty of Dentistry, Boroujerd Islamic Azad University, Boroujerd P.O 6915136111, Iran

Full list of author information is available at the end of the article
}

coronavirus (SARS-CoV-2) causes serious acute respiratory diseases including pneumonia and bronchitis with approximately $2.3 \%$ fatality occurrence $[8,9]$. The most prevalent signs and symptoms are cough (76\%), fever (98\%), myalgia or fatigue (44\%), and dyspnea (55\%). The SARS-CoV-2 incubation period has been reported to be 1-14 days, and asymptomatic individuals may also involve in the spread of this virus [10-13]. Due to the significant human-to-human route of contamination of these coronaviruses, dentists according to their close contact with patients are at danger of SARS-CoV-2 in dental procedures [5]. Even though all routine dental treatment in countries with SARS-CoV-2 infection has been postponed during the pandemic era, the need for emergency care provided by teams with sufficient personal protective equipment takes priority [14].

\section{Treatment planning approaches}

As a general principle, all non-emergent dental care for all individuals should be deferred during the pandemic crisis [15]. However, since the social demand for 
emergency care services even during this situation will be crucial [16], in situations that are considered an emergency according to the therapist's judgment, the patient should be called to the office for the most possible conservative treatment $[17,18]$. Dentists must be available to their patients for emergency care. Therefore, during pandemics, considering the infection control principles, our approach to treatments can be classified into four main categories:

1. Treatments that can be accomplished using their standard conventional approach.

2. Treatments that can be accomplished using a modified approach.

3. Interim treatments that are performed only to eliminate severe pain or potentially serious patient's life- or health-threatening conditions so that definitive treatment can be accomplished later.

4. Treatments that should be avoided; instead, available alternative treatment options should be applied.

\section{Recommendations for clinical interventions}

- If basic personal protection equipment (PPE), such as facemask and gloves, are not available, regardless of the urgency of the condition, any treatment cannot be proceeding.

- For patients who are incapable of mouthrinsing (such as children), the application of a rubber dam for aerosol-generating procedures is recommended. In addition, cotton rolls soaking is a suitable substitute for the pre-procedural rinsing.

- Avoid or minimize procedures that may induce coughing, such as taking intraoral x-rays. Instead, extra oral radiographs, such as panoramic and
$\mathrm{CBCT}$, are proper alternatives because they will not induce coughing.

- Aerosol-generating treatments are strongly recommended to be avoided.

- Manual instruments are an appropriate alternative to minimize the generation of aerosols.

- Sometimes, for patients with a serious emergency condition, it may be an inevitable option to extract highly infectious teeth with a questionable prognosis that under normal circumstances could have had their prognosis improved by being treated.

- Also, when definitive treatment is not possible due to infection control considerations, pulpotomy using MTA can be a good alternative for root canal therapy (RCT) for the management of symptomatic mature permanent teeth.

- To minimize the generation of droplets and aerosols in cases that aerosol-generating treatments are irreplaceable, four-handed operation (Fig. 1), high evacuation ejector, and rubber dam can be beneficial.

- Spatter-generating treatments are advised to be scheduled as the last appointments of the shift.

- As a serious source of cross-infection, dental health care providers should know that backflow may occur during the use of a saliva ejector.

- To minimize the need for recall appointments, the use of resorbable sutures is recommended.

- Consider avoiding the application of instruments that are not easily disinfected (Table 1) [19-29].

\section{Fundamental elements needed to prevent transmission of SARS-CoV-2 virus in dental healthcare settings}

Administrative measures

Administrative measures are all infrastructures to implement, guide, support, and monitor adherence to standard
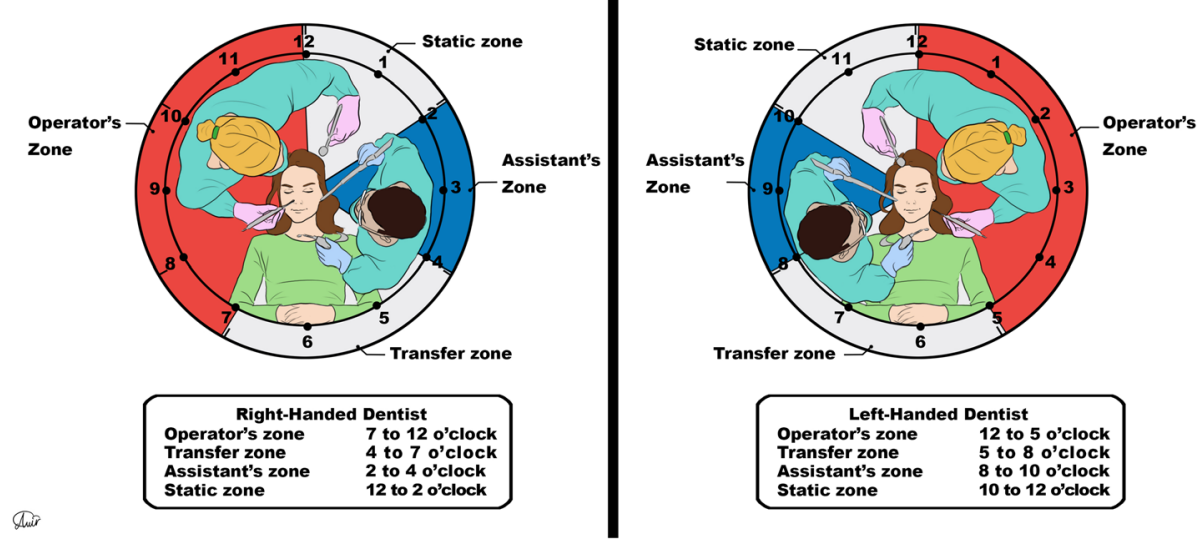

Fig. 1 Four-handed dentistry. Zones of activity for right-handed and left-handed dentists 
Table 1 Factors related to aerosol contamination

\begin{tabular}{|c|c|}
\hline Device, instruments, measures & Description \\
\hline Ultrasonic and sonic scalers & $\begin{array}{l}\text { - They generate the highest rate of aerosols in a } 6-12 \text {-in diameter from the operator. } \\
\text { - The application of high volume evacuators reduces airborne contamination by } 95 \% \text {. }\end{array}$ \\
\hline Air polishing & $\begin{array}{l}\text { - Airborne contamination of air polishing is almost equal to ultrasonic scalers. } \\
\text { - The application of high-volume evacuator and/or aerosol reduction device reduces airborne contaminations } \\
\text { up to } 95 \% \text {. }\end{array}$ \\
\hline Air-water syringe & $\begin{array}{l}\text { - Airborne contamination of air-water syringes is almost equal to ultrasonic scalers. } \\
\text { - However, the application of high-volume evacuators can reduce airborne contamination by nearly } 99 \% \text {. }\end{array}$ \\
\hline $\begin{array}{l}\text { High speed air turbine } \\
\text { handpiece }\end{array}$ & $\begin{array}{l}\text { - An air-driven handpiece is powered by compressed air to spin the air-driven turbine. } \\
\text { - Air-driven handpieces reach speeds of up to } 400,000 \mathrm{rpm} \text { in a variety of torques. } \\
\text { - The water flow speeds for turbines with one, two, and three coolant apertures are } 42.38,34.31 \text {, and } 30.44 \mathrm{~mL} / \\
\text { min, respectively, or about } 1.0 \mathrm{ml} / \mathrm{s} \text {. } \\
\text { - High-speed dental handpieces without anti-retraction valves aspirate the debris and fluids and contaminate } \\
\text { the air and water systems of the unit which may lead to cross-infection. }\end{array}$ \\
\hline Slow speed handpieces & $\begin{array}{l}\text { - The speed of their inbuilt motor can reach up to } 80,000 \mathrm{rpm} \text {. } \\
\text { - The average pressure for air and external water in these handpieces are about } 0.25-0.3(\mathrm{Mpa}) \text { and } 198(\mathrm{Kpa}) \text {, } \\
\text { respectively. } \\
\text { - The average water flow in these handpieces is about } 90-110(\mathrm{~min} / \mathrm{ml}) \text {. }\end{array}$ \\
\hline
\end{tabular}

Anti-retraction high-speed dental . These handpieces reduce the microbial backflow into the tubes of the handpieces and dental units. handpiece

Electric motor handpieces

Tooth preparation with air abrasion

Aerosol reduction device

Rubber dam

High-volume evacuator

Ultraviolet radiation

Patient and dentist position

Ventilation and air-conditioning system

Microbiological control of unit water system

Preprocedural mouth-rinse

Manual instruments
- Self-contained internal gearings in an electric motor handpiece enable it to function at a stable torque and speeds up to $200,000 \mathrm{rpm}$.

- Extensive microbial contamination with abrasive particles has been demonstrated.

- Aerosol reduction devices such as Jet Shield (DENTSPLY SIRONA INC., USA) can reduce the contamination up to $97 \%$ during air polishing.

- Rubber dams minimize the formation of the blood- and saliva-contaminated aerosols.

- The application of rubber dam reduces airborne particles in 1-meter diameter of the source of particle production by $70 \%$.

- High-volume evacuators can efficiently reduce the number of microorganisms, blood, and material released into the air.

- Since a small-bore saliva ejector is not an adequate substitute, when a four-handed operation is not an option, utilization of a high-volume evacuator attached to the instrument is necessary.

- The use of these types of evacuators when the utilization of a rubber dam is impractical can be highly beneficial.

- Researches indicated that the application of high-velocity evacuators with air polishers can reduce CFUs about $94.8 \%$.

- Ultra-violet radiation can be considered as a highly fungicidal, viricidal, and bactericidal agent via damaging DNA and denaturation of proteins.

- The International Ultraviolet Association (IUVA) stated that UV disinfection can reduce the transmission of the SARS-COV-2 in air, water, and on surfaces.

- The patient in the supine position enables the dental team to stay away from the patient's breathing way.

- To reduce environmental contamination and prevent contaminated air circulation

- Periodic disinfection of the unit water system via application of chemicals and distilled water.

- The efficiency of chlorhexidine on SARS-CoV-2 has not yet been studied. However, the use of $1 \%$ hydrogen peroxide or $0.2 \%$ povidone-iodine is recommended.

- Prophylactic administration of mouthwash reduces the microbial load in the oral cavity.

- Manual instruments are recommended to minimize the aerosol generation. and Transmission-Based Precautions. A key administrative measure is provision of necessary and sufficient fiscal and human resources for maintaining infection control (IC) programs. Specific components include adequate staff, inclusion of infection control practices (ICP) in dental facility construction and design decisions, adequate supplies, equipment, and compliance monitoring [30].

Infection control practice landscape in dental settings Studies show that in general, knowledge and attitudes regarding infection control are good; however, the compliance 
and practice levels regarding the same are low [31-36]. Findings indicate that lack of compliance with ICP is multifactorial, and compliance with recommended IC guidelines is challenging, and the results of some studies indicate that compliance is achievable, even in medium and large group practices [32, 37-39].

\section{Organizational and individual factors that affect ICP compliance}

A review of the literature concluded that variations in organizational factors (e.g., safety climate, policies and procedures, education and training, adequate resourcing, innovation culture, staff education, and adequate highly trained and experienced staff) and individual factors (e.g., knowledge, perceptions of risk, and past experience) were determinants of adherence to ICP for protection against SARS and other respiratory pathogens [4043].

\section{Education of dental health care providers (DHCP)}

A study on Hong Kong hospital workers demonstrated that the likelihood of SARS infection was strongly associated with having less than $2 \mathrm{~h}$ of infection control (IC) training and not understanding infection control procedures [44]. It is important to realize that IC education and training goal are not a simple memorization of protocols. Further attempts to fill the gap between knowledge and practice change should be made [43]. Implementing problem-based learning, evidence-based practice methods, practical demonstration and participation actions, incorporating individual experience, and hands-on training is associated with decreased healthcare-associated infections (HAI) and hand hygiene compliance [45-47]. Strong recurrent $\mathrm{HCP}$ education and training with the aim to reduce specific types of infections is effective for guideline implementation [47].

\section{Personal protection equipment (PPE) for DHCP}

Personal protection equipment (PPE) reduces the risk of contamination, and healthcare workers should take this issue seriously [48]. For SARS-CoV-2, recommendations for PPE are masks, respirators, gloves, goggles or face shields, and long gowns $[49,50]$. More body coverage leads to better protection. Donning and doffing of PPE should be easy [51] since the complexity of use leads to an increased risk of self-contamination especially during doffing [52]. The correct sequence of donning and doffing is depicted in Figs. 2, 3, 4, and 5.

\section{Masks and respirators}

Waterproof surgical masks prevent the spread of respiratory droplets in the environment and protect staff against both infected droplets and contact contamination. Also, they reduce the risk of SARS-CoV-2 contamination by at least $80 \%$ [2]. Filtering facepiece respirators (FFRs) including N95 respirators is known as

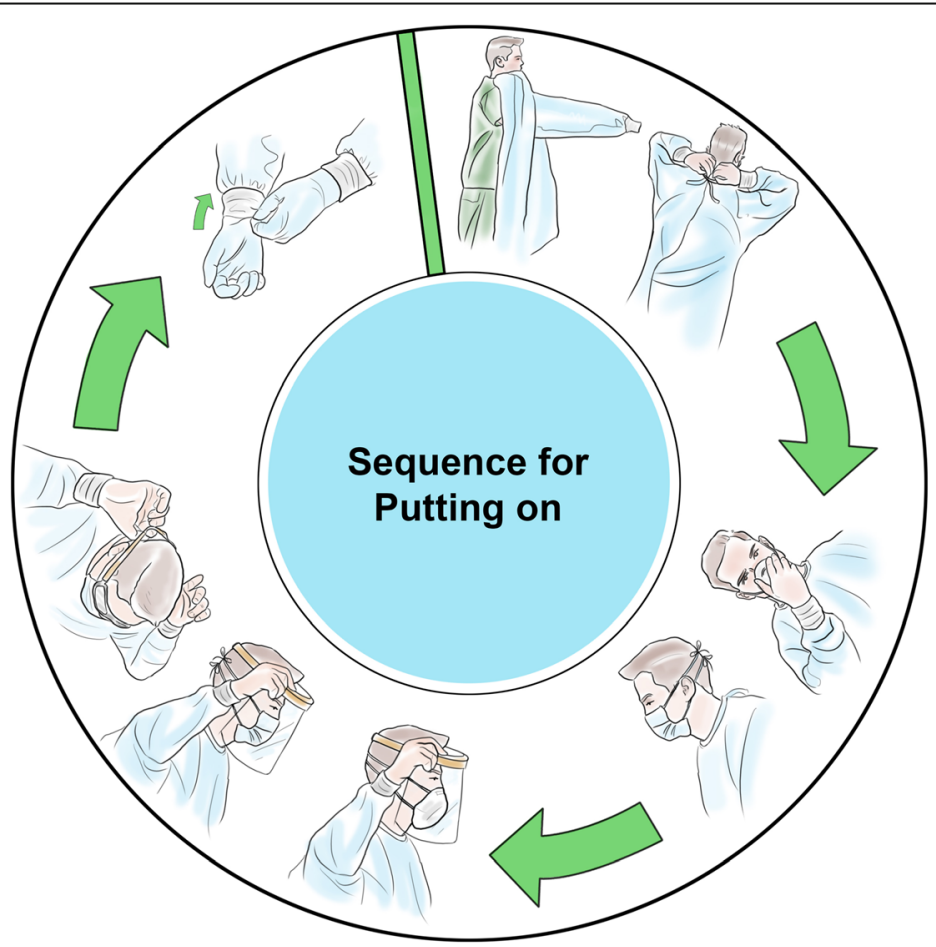

Fig. 2 Personal protection equipment donning order 


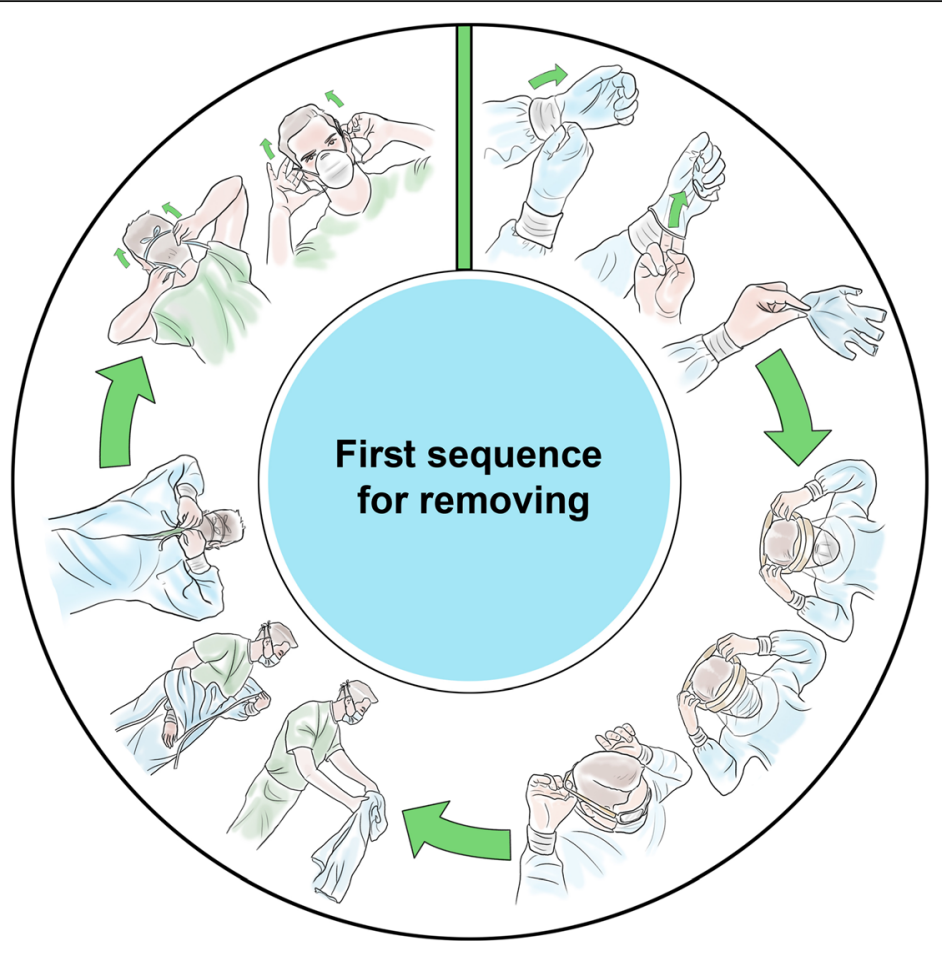

Fig. 3 Personal protection equipment doffing first order

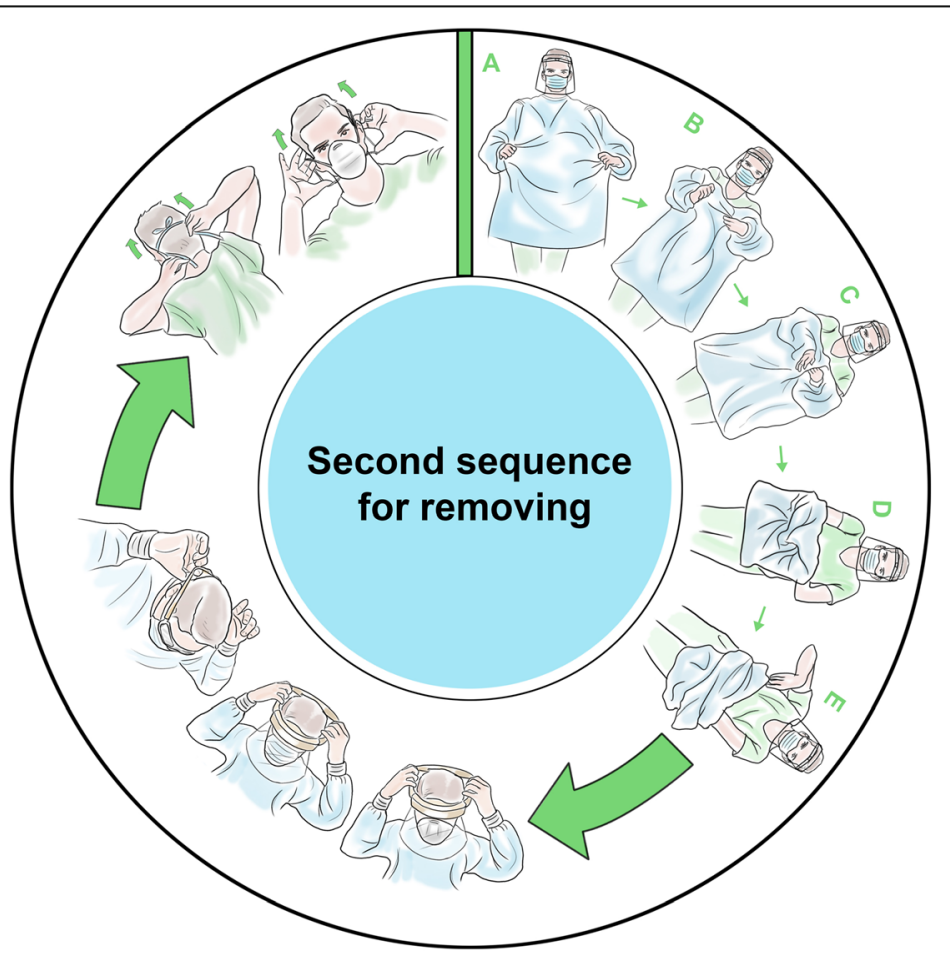




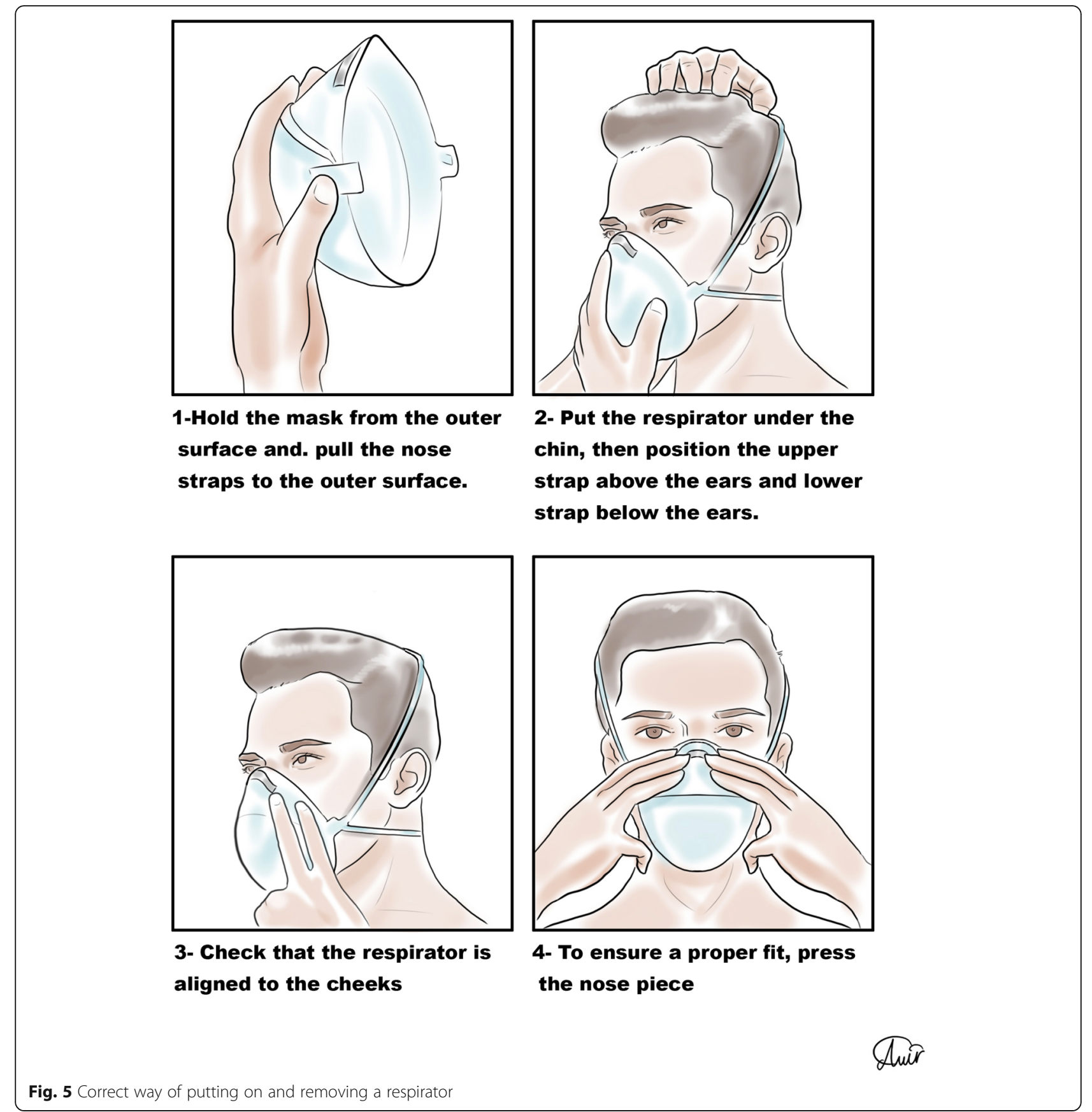

effective and protective equipment that their filtration has been achieved via a network of polypropylene microfibers and electrostatic charges [53]. A meta-analysis revealed that there is no statistically significant difference between surgical masks and facepiece respirators such as FFPs and N95 in terms of protection against airborne viral infections $(\mathrm{RR}=0.89, p>0.05)$ [54]. Powered airpurifying respirator (PAPR) is also recommended for protection against SARS-CoV-2 [55]. However, due to the electronic nature of this device and the possibility of damage to the electronic parts of it, it is recommended to use it simultaneously with a filtering facepiece respirator [56]. Reusable elastomeric respirators are not commonly used in health care settings and are used widely in the industry and are available in full-face, half-face, and quarter-face models [57]. Comparisons between different masks and respirators are shown in Table 2 [57].

Due to the SARS-CoV-2 pandemic and the reduction in access to face masks and respirators such as the N95, the CDC recommends methods for extended use and reuse of them [58]. For extended use, the $\mathrm{CDC}$ recommends using an N95 respirator for up to 
Table 2 A brief comparison between masks and respirators

\begin{tabular}{|c|c|c|c|c|c|}
\hline Mask type & Standard & \multicolumn{3}{|c|}{ Filtration effectiveness } & Re-usability \\
\hline $\begin{array}{l}\text { Single-use medical } \\
\text { masks }\end{array}$ & China: YY/T0969 & \multicolumn{3}{|c|}{$\begin{array}{l}3.0 \text { microns: > 95\% } \\
0.1 \text { microns: not effective }\end{array}$} & No \\
\hline Surgical masks & China : YY 0469 & \multicolumn{3}{|l|}{$\begin{array}{l}3.0 \text { microns: > 95\% } \\
0.1 \text { microns: > 30\% }\end{array}$} & No \\
\hline \multirow[t]{2}{*}{ Surgical masks } & \multirow[t]{2}{*}{ USA: ASTM F2100 } & Level 1 & \multicolumn{2}{|l|}{ Level 2, 3} & No \\
\hline & & $\begin{array}{l}3.0 \text { microns: > 95\% } \\
0.1 \text { microns: > 95\% }\end{array}$ & \multicolumn{2}{|l|}{$\begin{array}{l}3.0 \text { microns: > 95\% } \\
0.1 \text { microns: > 95\% }\end{array}$} & \\
\hline \multirow[t]{2}{*}{ Surgical masks } & \multirow[t]{2}{*}{ Europe: EN 14683} & Type 1 & \multicolumn{2}{|l|}{ Type 2,3 } & No \\
\hline & & $\begin{array}{l}3.0 \text { microns: > 95\% } \\
0.1 \text { microns: }>95 \%\end{array}$ & \multicolumn{2}{|l|}{$\begin{array}{l}3.0 \text { microns: > 95\% } \\
0.1 \text { microns: }>95 \%\end{array}$} & \\
\hline \multirow[t]{2}{*}{ Respirator masks } & \multirow{2}{*}{$\begin{array}{l}\text { USA: NIOSH } 42 \text { CFR } \\
84\end{array}$} & N95 & N99 & N100 & Yes (under especial conditions) \\
\hline & & 0.3 microns: > 95\% & 0.3 microns: > 99\% & 0.3 microns: > 99.97\% & \\
\hline \multirow[t]{2}{*}{ Respirator masks } & \multirow[t]{2}{*}{ Europe: EN 149: 2001} & FFP1 & FFP2 & FFP3 & Yes (under especial conditions) \\
\hline & & 0.3 microns : $>80 \%$ & 0.3 microns : $>94 \%$ & 0.3 microns : >99\% & \\
\hline Elastomeric respirators & $\begin{array}{l}\text { USA: NIOSH } 42 \text { CFR } \\
84\end{array}$ & \multicolumn{3}{|l|}{10 to 50 APF } & Yes \\
\hline PAPR & $\begin{array}{l}\text { USA: NIOSH } 42 \text { CFR } \\
84\end{array}$ & \multicolumn{3}{|l|}{$1000 \mathrm{APF}$} & Yes \\
\hline
\end{tabular}

PAPR powered air-purifying respirator. APF assigned protection factor

$8 \mathrm{~h}$; however, it is recommended to follow the manufacturer's instructions. Based on CDC, it should be noted that FFRs can be reused up to 5 times via the following strategies:

1) Mask rotation: In this technique, the masks must be numbered and used in turn. The minimum time for not using a used mask should be at least $72 \mathrm{~h}$, as the SARS-CoV-2 loses its viability. However, if a mask is damaged or used in the aerosol-generating process, it should be discarded.

2) Reprocessing/decontamination: Hydrogen peroxide vaporization can be used on N95 models that do not contain cellulose, such as the 1860 model. Also, methods such as proper UV treatment of $\mathrm{N} 95$ masks, moist heat (heating at $60-70{ }^{\circ} \mathrm{C}$ and $80-85 \%$ relative humidity), and dry heating of the mask at $70^{\circ} \mathrm{C}$ for $30 \mathrm{~min}$ can be used for decontamination; however, dry and moist heat is not currently recommended for SARS-CoV-2.

\section{Gowns}

Different qualities have been reported for gowns [59]. Most models of isolation gowns often leave the neck exposed, which can be a route of contamination [60]. The most protection is assigned to coveralls followed by long gowns, gowns, and aprons, respectively [51]. According to the studies, modified gowns with attached gloves, cover the wrist area, and gowns that fit tightly at the neck area reduce the risk of contamination in the best way [51]. It is also recommended that the gowns be removed simultaneously with the gloves [51].

\section{Gloves}

Adding tabs to the gloves for taking them off from the hands reduces the risk of contamination [51]. Studies showed that the risk of contamination using double or triple gloves is less than single glove. Also, donning three layers of gloves due to the complex doffing process is not suggested due to more risk of self-contamination $[61,62]$. Cleaning of gloves with hypochlorite or quaternary ammonium except alcohol-based hand rubs may decrease hand contamination [51]. Dentists should use arm-length surgical gloves (Fig. 6) [63].

\section{Eye protectors}

Lindsley et al. used breathing and coughing simulators to determine the efficacy of face shields in reducing contamination. They proved that face shields are effective in reducing the exposure to large infectious particles, but smaller particles are able to remain airborne and flow around a face shield to be inhaled [64]. Face shields are more bulky than goggles and protect the entire face [64]. Figure 7 shows a standard eye protector providing full eye seal. 


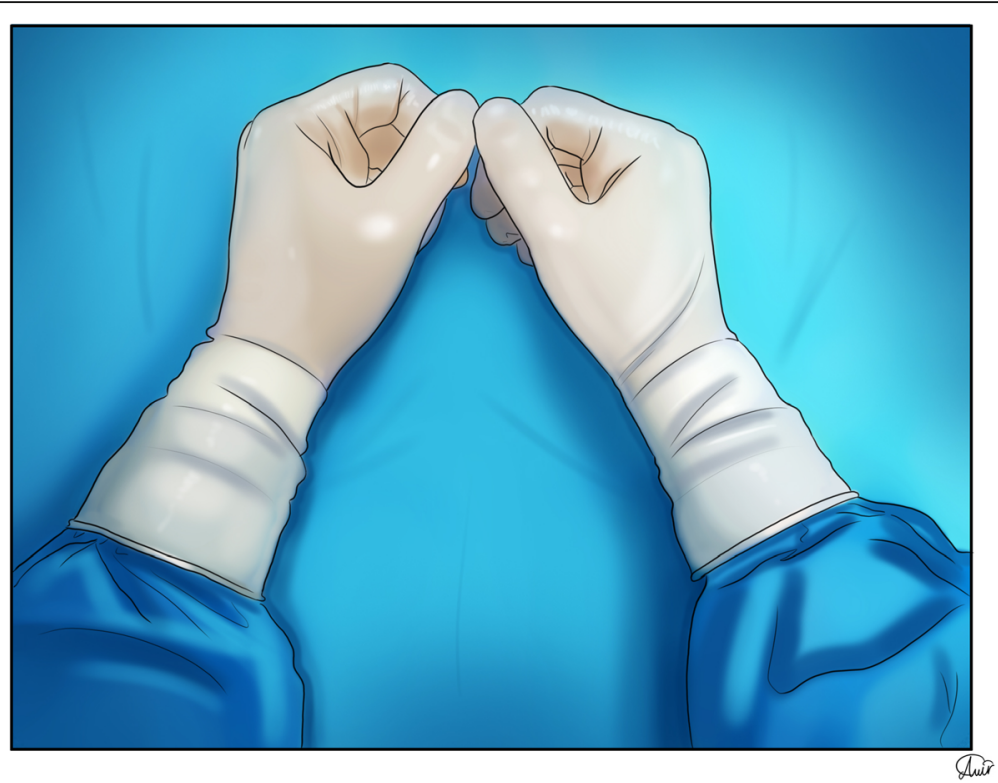

Fig. 6 Arm-length surgical gloves that completely cover the wrist area
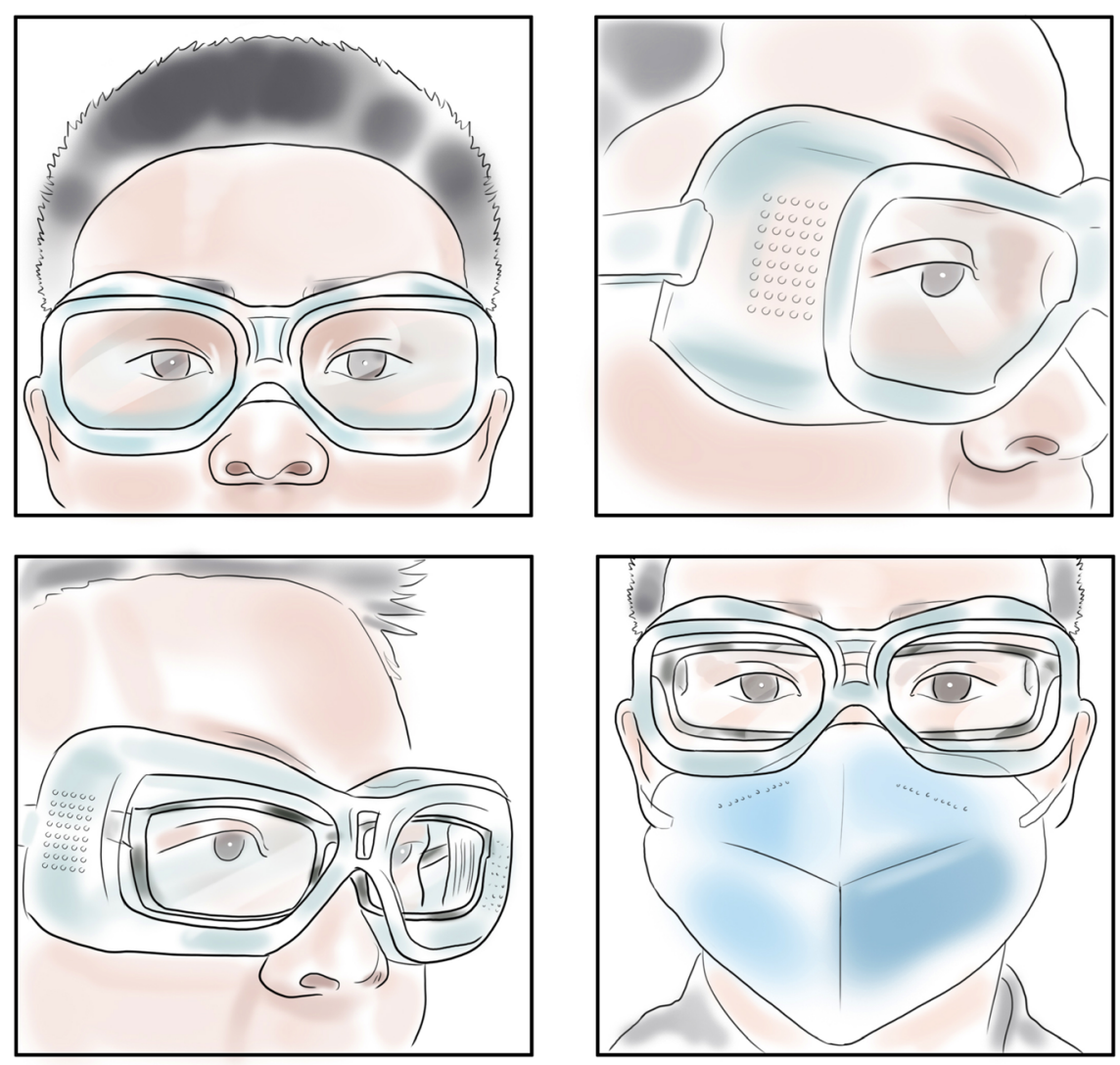

Suir

Fig. 7 A proper goggles provide a complete eye seal 


\section{Hand hygiene}

It has been shown that hand hygiene does not provide an adequate defensive response to viruses without the use of face masks [65]. Ethanol is widely used in the world for hand rubbing in various forms including gels and foams [66]. Also, using alcohol-based disinfectants are promising substances to protect healthcare workers against SARS-CoV-2 [67]. The mechanism of alcoholbased sanitizers is denaturing proteins so that enveloped viruses including coronaviruses are removed by using these sanitizers [68]. Reports demonstrated that alcohol-based hand rubs could contain at least $60 \%$ ethanol to provide effective protection [69]. In $5 \mathrm{mo}$ ments, healthcare workers should consider hand rubbing seriously: before touching a patient, before aseptic treatments, after exposure to body fluids, after touching a patient, and after touching the patients' surroundings (Fig. 8) [70].

\section{Environmental measures}

Cleaning and disinfecting non-critical surfaces in patient-care areas are part of standard precautions. In general, these procedures do not need to be changed for patients on transmission-based precautions and are appropriate for SARS-CoV-2 in healthcare settings, including those patient-care areas in which aerosol-generating procedures are performed. The cleaning and disinfection of all patient-care areas are important for frequently touched surfaces, especially those closest to the patient, that are most likely to be contaminated (e.g., dental chair, cabinets, doorknobs, desks, elevators, bathroom sinks, surfaces, and equipment in close proximity to the patient). The frequency or intensity of cleaning may need to change based on the patient's level of hygiene and the degree of environmental contamination and for certain for infectious agents whose reservoir is the intestinal tract [71, 30, $72,73]$. A summary of the substances used for disinfecting and cleaning is presented in Table 3 [74-87].

\section{Adjunctive measures}

Prophylactic medication for dental health care providers Currently, there is no available and reliable evidence to support the prophylactic use of a medication(s) for dental health care providers, although a handful of trials in

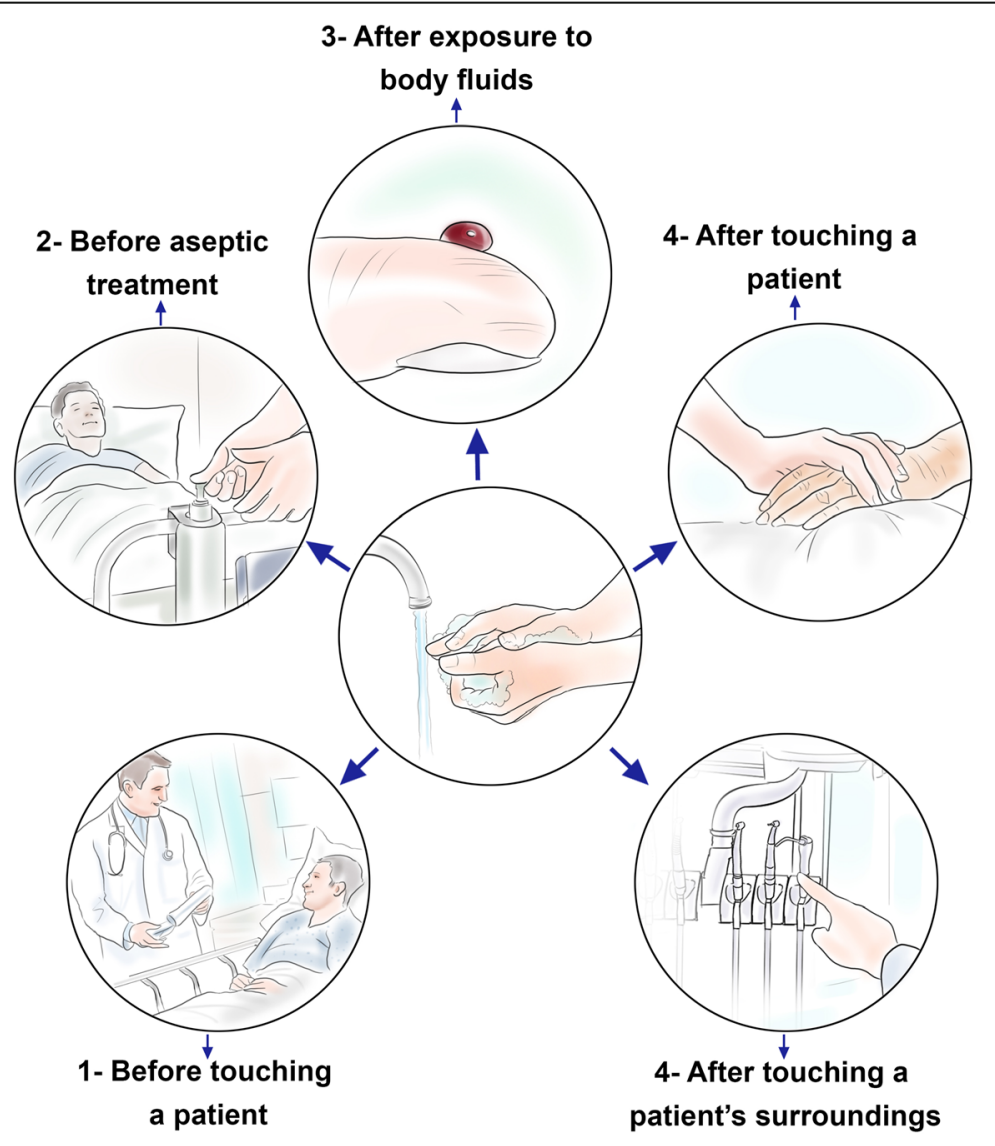

Fig. 8 Five main times that hand hygiene should be considered seriously 
Table 3 Methods of disinfecting non-critical surfaces in patient-care areas

\begin{tabular}{|c|c|c|c|}
\hline \multicolumn{4}{|c|}{ Disinfecting non-critical surfaces in patient-care areas } \\
\hline \multicolumn{2}{|l|}{ Vaporized hydrogen peroxide } & \multicolumn{2}{|l|}{ Disinfectants } \\
\hline Types & Virucidal efficacy & Hypochlorous acid (HOCl) & $\begin{array}{l}\text { Other } \\
\text { disinfectants }\end{array}$ \\
\hline \multirow{2}{*}{$\begin{array}{l}\text { Non-condensing vaporized hydrogen } \\
\text { peroxide (VHP) technology (Steris) and } \\
\text { condensing search hydrogen peroxide } \\
\text { vapour (HPV) technology (Bioquell) }\end{array}$} & \multirow[b]{2}{*}{$\begin{array}{l}\text { Limited evidence is available for the virucidal } \\
\text { activity of condensing HPV systems. Recently, } \\
\text { several studies have demonstrated the } \\
\text { in vitro activity of condensing HPV systems } \\
\text { against individual viruses, including feline } \\
\text { calicivirus (FCV), adenovirus, lactococcal } \\
\text { bacteriophages6, and MS2 coliphage }\end{array}$} & Virucidal efficacy & \multirow{2}{*}{$\begin{array}{l}\text { Alkalis, } \\
\text { oxidizing } \\
\text { agents, } \\
\text { alcohols, and } \\
\text { aldehydes }\end{array}$} \\
\hline & & $\begin{array}{l}\text { - Virucidal ability of solutions } \\
\text { containing a high amount of } \mathrm{HOCl} \text { is } \\
\text { better than those containing } \mathrm{HCl} \\
\text { - Reduction of efficacy after spraying } \\
\text { from a distance more than } 30 \mathrm{~cm} \\
\text { - Minimum concentration should be } \\
\text { more than } 40 \text { ppm for effective } \\
\text { virucidal effect } \\
\text { - The } 100 \text { and } 200 \text { ppm concentrated } \\
\text { solutions inactivated more than } 99.9 \% \\
\text { of Alv directly after spraying, while } \\
\text { the } 50 \text { ppm concentration required at } \\
\text { least } 3 \text { min of contact }\end{array}$ & \\
\hline
\end{tabular}

the world are being conducted to keep health care providers and vulnerable people safe from SARS-CoV-2 during the pandemic. Until further information, the focus of the dental health care providers should be on maximum application of safety regulations and recommendations by their local dental boards.

\section{Immunization}

By far, three different types of coronaviruses (SARS$\mathrm{CoV}$, MERS-CoV, and SARS-CoV-2) have considerably affected global health in about 20 years; nonetheless, there is still no approved vaccines for these viruses [88]. Although currently numerous preclinical and clinical trials are being conducted with some promising results [88], it is noteworthy that one major drawback is that RNA viruses usually have higher mutation rates compared to DNA viruses, resulting in challenges for vaccine development [89]. Nevertheless, numerous pharmaceutical companies are actively involved in the different stages of vaccine development. In case of the development of an effective vaccine, dental health care providers, unarguably, should be among the first groups of professionals who receive the vaccine.

\section{Rapid point of care tests in dental offices}

Currently, two major types of testing are available according to centers for disease control and prevention: viral testing and antibody testing indicating if the person does have a current infection or indicating if there was a previous infection, respectively. American Dental Association newsletter on April 17, 2020 urged dentists to be cautious about using novel coronavirus diagnostic tests before they have been properly evaluated and made available for dentists. Meanwhile, American Dental Association has sought federal recognition that licensed dentists may administer point of service tests authorized by the Food and Drug Administration (FDA) for novel coronavirus (SARS-CoV-2); however, because of the medical demand, currently, the medical suppliers are not planning on providing point-of-care tests to dentists in the very near future. It is noteworthy that at the present time, American Dental Association does not consider SARS-CoV-2 testing to be a scope of practice issue for dental offices according to ADA newsletter abovementioned. Although there is currently no FDA-approved or cleared test to diagnose or detect SARS-CoV-2, findings of some studies [90-93] may direct the future research into cheaper, faster, and more effective testing methods that would be available for the dental practices. A study conducted in a Hong Kong hospital reported consistent detection of coronavirus in the saliva of patients admitted from the first day that they were hospitalized [94]. In order to collect the samples, patients were instructed to cough out saliva from the throat into a sterile container that was later sent to the lab for analysis. This study underscored the advantage of simple and safe saliva sampling in a pandemic situation that can be actually utilized safely not only in the dental offices but also in anywhere including but not limited to busy clinics, airports, etc. [90]. It is of paramount importance that any testing method must strongly reduce the risk of SARS-CoV-2 transmission. Since Saliva may play a crucial role in the humanto-human transmission, salivary diagnostics might be an easy and cost-effective point-of-care platform for SARS-CoV-2 diagnosis because saliva self-collection will likely reduce the risk of SARS-CoV-2 transmission [91]. Additionally, the nasopharyngeal and oropharyngeal collection results in discomfort and possible bleeding especially in infected patients with thrombocytopenia that is potentially dangerous [91]. Our profession needs to emerge from this pandemic situation and probably enter a new world so maybe this testing method would become one of the routines in our daily practices. 


\section{Conclusion}

This article seeks to provide an overview of existing scientific evidence to suggest a guideline for reopening dental offices. We believe that studying this article and paying attention to its instructions can provide readers with an overview of the arrangements that should be considered for the gradual reopening of dental offices.

\begin{abstract}
Abbreviations
ADA: American Dental Association; APF: Assigned Protection Factor; CDC: Centers for Disease Control and Prevention; CFR: Code of Federal Regulations; CBCT: Cone-beam computed tomography; CoVs: Coronaviruses; DHCP: Dental health care providers; DNA: Deoxyribonucleic acid; FCV: Feline calicivirus; FFRs: Filtering facepiece respirators; FFP: Filtering facepiece; FDA: Food and Drug Administration; HAl: Healthcare-associated infections; HCP: Health care providers; HC1: Hydrochloric acid; HPV: Hydrogen peroxide vapour; HOC1: Hypochlorous acid; IC: Infection control; ICP: Infection control practices; IUVA: International Ultraviolet Association; KPa: Kilo pascal; MPa: Mega pascal; MERS-CoV: Middle East respiratory syndrome coronavirus; MTA: Mineral trioxide aggregate; NIOSH: National Institute for Occupational Safety and Health; PAPR: Powered air-purifying respirator; RNA: Ribonucleic acid; ppm: Part per million; PPE: Personal protection equipment; RCT: Root canal therapy; SARS-CoV-2: Severe acute respiratory syndrome coronavirus 2; SARS-CoV: Severe acute respiratory syndrome-related coronavirus; VHP: Vaporized hydrogen peroxide; UV: Ultraviolet
\end{abstract}

\section{Acknowledgements}

Not applicable

\section{Authors' contributions}

SOK, HRF, AM, VK, PM, and OM contributed substantially to the conception and design of the study and the acquisition of data. BC, PF, and BH provided critical revision of the article and provided final approval of the version to publish. BC as the corresponding author verify that all individuals who made contributions to this study are included either as authors or are acknowledged at the end of the paper. The authors read and approved the final manuscript.

\section{Funding}

This research received no specific grant from any funding agency in the public, commercial, or not-for-profit sectors.

\section{Availability of data and materials}

The datasets generated and/or analyzed during the current study are not publicly available due but are available from the corresponding author on reasonable request.

\section{Ethics approval and consent to participate}

Not applicable.

\section{Consent for publication}

Not applicable.

\section{Competing interests}

The author(s) declared no potential conflicts of interest with respect to the research, authorship, and/or publication of this article.

\footnotetext{
Author details

${ }^{1}$ CMFRC, National Advance Center for Craniomaxillofacial Reconstruction, Tehran, Iran. ${ }^{2}$ Craniomaxillofacial Research Center, Tehran University of Medical Sciences, Tehran, Iran. ${ }^{3}$ Dental Research Center, Research Institute of Dental Sciences, Shahid Beheshti University of Medical Sciences, Tehran, Iran. ${ }^{4}$ Private Practice, Kerman, Iran. ${ }^{5}$ Private Practice, El Paso, TX, USA. ${ }^{6}$ Private Practice, Austin, TX, USA. ${ }^{7}$ Department of Periodontology, Islamic Azad University, Tehran, Iran. ${ }^{8}$ Faculty of Dentistry, Boroujerd Islamic Azad University, Boroujerd P.O 6915136111, Iran. ${ }^{9}$ Faculty of Dentistry, Department of Oral and Maxillofacial Surgery, School of Dentistry, Zanjan University of Medical Sciences, Zanjan, Iran. ${ }^{10}$ Resident of prosthodontics, Isfahan
}

University of Medical Sciences, College of Dentistry, Isfahan, Iran. ${ }^{11}$ School of Dentistry, Shahid Beheshti University of Medical Sciences, Tehran, Iran.

Received: 28 May 2020 Accepted: 29 June 2020

Published online: 03 August 2020

\section{References}

1. Li G, Fan Y, Lai Y, Han T, Li Z, Zhou P et al (2020) Coronavirus infections and immune responses. J Med Virol 92(4):424-432

2. World Health Organization (2020) Infection prevention and control during health care when COVID-19 is suspected: interim guidance, 19 March 2020. [https://www.who.int/publications-detail-redirect/10665-331495]

3. Schoeman D, Fielding BC (2019) Coronavirus envelope protein: current knowledge. Virol J 16(1):69

4. Berry M, Gamieldien J, Fielding BC (2015) Identification of new respiratory viruses in the new millennium. Viruses 7(3):996-1019

5. Peng X, Xu X, Li Y, Cheng L, Zhou X, Ren B (2020) Transmission routes of 2019-nCoV and controls in dental practice. Int J Oral Sci 12(1):9

6. Zaki AM, van Boheemen S, Bestebroer TM, Osterhaus AD, Fouchier RA (2012) Isolation of a novel coronavirus from a man with pneumonia in Saudi Arabia. N Engl J Med 367(19):1814-1820

7. Tartaglia GM, Kumar S, Fornari CD, Corti E, Connelly ST (2017) Mouthwashes in the 21 (st) century: a narrative review about active molecules and effectiveness on the periodontal outcomes. Expert Opin Drug Deliv 14(8):973-982

8. Eurosurveillance Editorial T (2020) Note from the editors: novel coronavirus (2019-nCoV). Eurosurveillance 25(3):2001231

9. Zhao WM, Song SH, Chen ML, Zou D, Ma LN, Ma YK et al (2020) The 2019 novel coronavirus resource. Yi Chuan 42(2):212-221

10. Backer JA, Klinkenberg D, Wallinga J (2020) Incubation period of 2019 novel coronavirus (2019-nCoV) infections among travellers from Wuhan, China, 20-28 January 2020. Euro Surveill 25(5):2000062

11. Cheng VCC, Wong SC, Chen JHK, Yip CCY, Chuang WWM, Tsang OTY et al (2020) Escalating infection control response to the rapidly evolving epidemiology of the coronavirus disease 2019 (COVID-19) due to SARS-CoV2 in Hong Kong. Infect Control Hosp Epidemiol 41(5):493-498

12. W-j G, Ni Z-y HY, Liang W-h, C-q O, He J-x et al (2020) Clinical characteristics of 2019 novel coronavirus infection in China. MedRxiv 2020(2002):2006. 20020974

13. Huang C, Wang Y, Li X, Ren L, Zhao J, Hu Y et al (2020) Clinical features of patients infected with 2019 novel coronavirus in Wuhan, China. Lancet 395(10223):497-506

14. Coulthard P (2020) Dentistry and coronavirus (COVID-19) - moral decisionmaking. Br Dent J 228(7):503-505

15. Fallahi HR, Keyhan SO, Zandian D, Kim S-G, Cheshmi B (2020) Being a frontline dentist during the Covid-19 pandemic: a literature review. Maxillofac Plast Reconstr Surg 42:1-9

16. Alharbi A, Alharbi S, Alqaidi S (2020) Guidelines for dental care provision during the COVID-19 pandemic. Saudi Dent J 32(4):181-186

17. Dave M, Seoudi N, Coulthard P (2020) Urgent dental care for patients during the COVID-19 pandemic. Lancet 395(10232):1257

18. Guo H, Zhou Y, Liu X, Tan J (2020) The impact of the COVID-19 epidemic on the utilization of emergency dental services. J Dent Sci. https://doi.org/ 10.1016/j.jds.2020.02.002

19. International Ultraviolet Association (IUVA) (2020) IUVA Fact Sheet on UV Disinfection for COVID-19 http://www.iuva.org/. [http://www.iuva.org/IUVAFact-Sheet-on-UV-Disinfection-for-COVID-19\#]

20. Barnes JB, Harrel SK, Rivera-Hidalgo F (1998) Blood contamination of the aerosols produced by in vivo use of ultrasonic sealers. J Periodontol 69(4): 434-438

21. Bentley CD, Burkhart NW, Crawford JJ (1994) Evaluating spatter and aerosol contamination during dental procedures. J Am Dent Assoc 125(5):579-584

22. Cavalcanti BN, Serairdarian PI, Rode SM (2005) Water flow in high-speed handpieces. Quintessence Int 36(5):361-364

23. FMC, Hertford House (2018) A practice manager's guide to dental handpieces www.dentistry.co.uk. [https://www.dentistry.co.uk/2018/08/22/ practice-managers-guide-dental-handpieces/]

24. Harrel SK, Barnes JB, Rivera-Hidalgo F (1999) Aerosol reduction during air polishing. Quintessence Int 30(9):623-628

25. Harrel SK, Molinari J (2004) Aerosols and splatter in dentistry: a brief review of the literature and infection control implications. J Am Dent Assoc 135(4): 429-437 
26. Miller R, Micik R (1978) Air pollution and its control in the dental office. Dent Clin North Am 22(3):453-476

27. Muzzin KB, KING TB, BERRY CW (1999) Assessing the clinical effectiveness of an aerosol reduction device for the air polisher. J Am Dent Assoc 130(9): 1354-1359

28. Pîrvu C, Pătraşcu I, Pîrvu D, lonescu C (2014) The dentist's operating posture-ergonomic aspects. J Med Life 7(2):177

29. Bureau of Naval Personnel (1963) Advanced Speeds in Operative Dentistry. [https://books.google.com/books?id=HxCVxwEACAA]]

30. Jane D, Siegel M, Rhinehart E, Jackson M, Chiarello L (2007) Guideline for isolation precautions: preventing transmission of infectious agents in healthcare settings. 2007. Am J Infect Control 35:S65-S164

31. Al-Maweri SA, Tarakji B, Shugaa-Addin B, Al-Shamiri HM, Alaizari NA, AlMasri O (2015) Infection control: Knowledge and compliance among Saudi undergraduate dental students. GMS Hyg Infect Control 10:Doc10

32. Alharbi G, Shono N, Alballaa L, Aloufi A (2019) Knowledge, attitude and compliance of infection control guidelines among dental faculty members and students in KSU. BMC Oral Health 19(1):7

33. Binalrimal S, AlDrees A, AlWehaibi M, AlAsmary M, AlShammery A, AlHaidri $E$, et al. (2019) Awareness and compliance of dental students and interns toward infection control at Riyadh Elm University. GMS Hyg Infect Control 14:Doc10

34. Ghimire B, Chandra S (2018) Awareness of infection control among dental students and interns. JNMA J Nepal Med Assoc 56(210):598-601

35. Mutters NT, Hägele U, Hagenfeld D, Hellwig E, Frank U (2014) Compliance with infection control practices in an university hospital dental clinic. GMS Hyg Infect Control 9(3):Doc18

36. Porter S, El-Maaytah M, Afonso W, Scully C, Leung T (1995) Cross-infection compliance of UK dental staff and students. Oral Dis 1(4):198-200

37. Anders PL, Townsend NE, Davis EL, McCall W Jr (2016) Observed infection control compliance in a dental school: A natural experiment. Am J Infect Control 44(9):153-156

38. Harte JA, Charlton DG (2005) Characteristics of infection control programs in US Air Force dental clinics: a survey. J Am Dent Assoc 136(7):885-892

39. Porteous NB, Bizra E, Cothron A, Yeh C-K (2014) A survey of infection control teaching in US dental schools. J Dent Educ 78(2):187-194

40. Barker AK, Brown K, Siraj D, Ahsan M, Sengupta S, Safdar N (2017) Barriers and facilitators to infection control at a hospital in northern India: a qualitative study. Antimicrob Resist Infect Control 6(1):35

41. Dimick JB, Swoboda SM, Pronovost PJ, Lipsett PA (2001) Effect of nurse-topatient ratio in the intensive care unit on pulmonary complications and resource use after hepatectomy. Am J Crit Care 10(6):376

42. Garland KV (2013) A survey of United States dental hygienists' knowledge, attitudes, and practices with infection control guidelines. J Am Dent Hyg Assoc 87(3):140-151

43. Munksgaard Danmark (2006) En revurdering af demens: personen kommer i første række. [https://munksgaard.dk/products/en-revurdering-af-demensbog-16147-9788762804401]

44. Lau JT, Fung KS, Wong TW, Kim JH, Wong E, Chung S et al (2004) SARS transmission among hospital workers in Hong Kong. Emerg Infect Dis 10(2): 280

45. Berta W, Ginsburg L, Gilbart E, Lemieux-Charles L, Davis D (2013) What, why, and how care protocols are implemented in Ontario nursing homes. Can J Aging 32(1):73-85

46. Dekker M, Caris MG, Van Gunsteren AM, Van Mansfeld R, Lucas C, Vandenbroucke-Grauls CM (2017) Effectiveness of a behavioral approach to improve healthcare worker compliance with hospital dress code. Infect Control Hosp Epidemiol 38(12):1435-1440

47. Storr J, Twyman A, Zingg W, Damani N, Kilpatrick C, Reilly J et al (2017) Core components for effective infection prevention and control programmes: new WHO evidence-based recommendations. Antimicrob Resist Infect Control 6(1):6

48. Cook T (2020) Personal protective equipment during the coronavirus disease (COVID) 2019 pandemic - a narrative review. Anaesthesia 75(7): 920-927

49. World Health Organization (2020) Advice on the use of masks in the community, during home care and in healthcare settings in the context of the novel coronavirus ( 2019-nCoV) outbreak: interim guidance, 29 January 2020. [https://apps.who.int/iris/handle/10665/330987]

50. World Health Organization (2020) Rational use of personal protective equipment for coronavirus disease (COVID-19) and considerations during severe shortages: interim guidance, 6 April 2020. [https://apps.who.int/iris/ handle/10665/331695]

51. Verbeek JH, Rajamaki B, ljaz S, Sauni R, Toomey E, Blackwood B, et al. (2020) Personal protective equipment for preventing highly infectious diseases due to exposure to contaminated body fluids in healthcare staff. Cochrane Database Syst Rev 4(4):Cd011621

52. Roberge RJ (2008) Evaluation of the rationale for concurrent use of N95 filtering facepiece respirators with loose-fitting powered air-purifying respirators during aerosol-generating medical procedures. Am J Infect Control 36(2):135-141

53. Respiratory protective devices - Filtering halfmasks to protect against particles - Requirements, testing,marking (2001). [http://www.nobelcert. com/DataFiles/FreeUpload/EN\%20149-2001\%20plus\%20A1-2009.pdf]

54. Long Y, Hu T, Liu L, Chen R, Guo Q, Yang L et al (2020) Effectiveness of N95 respirators versus surgical masks against influenza: a systematic review and meta-analysis. J Evid Based Med 13(2):93-101

55. Saadi RA, Bann DV, Patel VA, Goldenberg D, May J, Isildak H (2020) A commentary on safety precautions for otologic surgery during the COVID19 pandemic. Otolaryngol Head Neck Surg 162(6):797-799

56. Roberge MR, Vojtko MR, Roberge RJ, Vojtko RJ, Landsittel DP (2008) Wearing an N95 respirator concurrently with a powered air-purifying respirator: effect on protection factor. Respir Care 53(12):1685-1690

57. National Academies of Sciences. Reusable elastomeric respirators in health care: considerations for routine and surge use. Washington (DC): National Academies Press (US); 2018 Dec 6. 3, Implementing Reusable Elastomeric Respirators in Health Care Settings: Routine and Surge Use (2019). [https:// www.ncbi.nlm.nih.gov/books/NBK540080/]

58. Centers for Disease Control Prevention: Recommended guidance for extended use and limited reuse of N95 filtering facepiece respirators in healthcare settings (2014). [https://www.cdc.gov/niosh/topics/hcwcontrols/ recommendedguidanceextuse.html]

59. Balci FSK (2016) Isolation gowns in health care settings: Laboratory studies, regulations and standards, and potential barriers of gown selection and use. Am J Infect Control 44(1):104-111

60. Zamora JE, Murdoch J, Simchison B, Day AG (2006) Contamination: a comparison of 2 personal protective systems. Can Med Assoc J 175(3):249254

61. Casanova LM, Rutala WA, Weber DJ, Sobsey MD (2012) Effect of singleversus double-gloving on virus transfer to health care workers' skin and clothing during removal of personal protective equipment. Am J Infect Control 40(4):369-374

62. Osei-Bonsu K, Masroor N, Cooper K, Doern C, Jefferson KK, Major $\mathrm{Y}$ et al (2019) Alternative doffing strategies of personal protective equipment to prevent self-contamination in the health care setting. Am J Infect Control 47(5):534-539

63. Bell T, Smoot J, Patterson J, Smalligan R, Jordan R (2015) Ebola virus disease: the use of fluorescents as markers of contamination for personal protective equipment. IDCases 2(1):27-30

64. Lindsley WG, Noti JD, Blachere FM, Szalajda JV, Beezhold DH (2014) Efficacy of face shields against cough aerosol droplets from a cough simulator. J Occup Environ Hyg 11(8):509-518

65. Wong WW, Cowling BJ, Aiello AE (2014) Hand hygiene and risk of influenza virus infections in the community: a systematic review and meta-analysis. Epidemiol Infect 142(5):922-932

66. Kampf G (2018) Efficacy of ethanol against viruses in hand disinfection. J Hosp Infect 98(4):331-338

67. World Health Organization (2020) Infection prevention and control during health care when novel coronavirus ( $\mathrm{nCoV}$ ) infection is suspected: interim guidance, January 2020. [https://apps.who.int/iris/handle/10665/330674]

68. Nicolle L (2003) SARS safety and science. Can J Anaesth 50(10):983-985 985988

69. Lotfinejad N, Peters A, Pittet D (2020) Hand hygiene and the novel coronavirus pandemic: the role of healthcare workers. J Hosp Infect. https:// doi.org/10.1016/j.jhin.2020.03.017

70. Lotfinejad N, Assadi R, Aelami MH, Pittet D (2020) Emojis in public health and how they might be used for hand hygiene and infection prevention and control. Antimicrob Resist Infect Control 9(1):1-6

71. Cheung KS, Hung IF, Chan PP, Lung K, Tso E, Liu R et al (2020) Gastrointestinal manifestations of SARS-CoV-2 infection and virus load in fecal samples from the Hong Kong cohort and systematic review and metaanalysis. Gastroenterology. https://doi.org/10.1053/j.gastro.2020.03.065 
72. Yeo C, Kaushal S, Yeo D (2020) Enteric involvement of coronaviruses: is faecal-oral transmission of SARS-CoV-2 possible? Lancet 5(4):335-337

73. Yuen K-S, Ye Z-W, Fung S-Y, Chan C-P, Jin D-Y (2020) SARS-CoV-2 and COVID-19: The most important research questions. Cell Biosci 10(1):1-5

74. Barbut F, Yezli S, Otter J (2012) Activity in vitro of hydrogen peroxide vapour against Clostridium difficile spores. J Hosp Infect 80(1):85-87

75. Bentley K, Dove B, Parks S, Walker J, Bennett A (2012) Hydrogen peroxide vapour decontamination of surfaces artificially contaminated with norovirus surrogate feline calicivirus. J Hosp Infect 80(2):116-121

76. Berrie E, Andrews L, Yezli S, Otter J (2011) Hydrogen peroxide vapour (HPV) inactivation of adenovirus. Lett Appl Microbiol 52(5):555-558

77. Clifford White G (1999) The handbook of chlorination and alternative disinfectants. 8678-8679 p.

78. Hao X, Li B, Zhang Q, Lin BZ, Ge L, Wang C et al (2013) Disinfection effectiveness of slightly acidic electrolysed water in swine barns. J Appl Microbiol 115(3):703-710

79. Heckert R, Best M, Jordan L, Dulac G, Eddington D, Sterritt W (1997) Efficacy of vaporized hydrogen peroxide against exotic animal viruses. Appl Environ Microbiol 63(10):3916-3918

80. Maillard J (1997) Viricidal activity and mechanisms of action of biocides. Sci Prog 80:287-315

81. Otter J, Yezli S, Perl TM, Barbut F, French G (2013) The role of 'notouch'automated room disinfection systems in infection prevention and control. J Hosp Infect 83(1):1-13

82. Pottage T, Richardson C, Parks S, Walker J, Bennett A (2010) Evaluation of hydrogen peroxide gaseous disinfection systems to decontaminate viruses. J Hosp Infect 74(1):55-61

83. Quinn PJ, Markey BK (2001) Disinfection and disease prevention in veterinary medicine. Disinfection, sterilization and preservation 5th edition Philadelphia: Lippincott, Williams \& Wilkins:1069-1 103

84. Rice EW, Adcock NJ, Sivaganesan M, Brown JD, Stallknecht DE, Swayne DE (2007) Chlorine inactivation of highly pathogenic avian influenza virus (H5N1). Emerg Infect Dis 13(10):1568

85. Russell AD (2004) Factors influencing the efficacy of antimicrobial agents. Principles and Practice of Disinfection, Sterilization and Preservation A Fraise. P Lambert y JY Maillard (Edts) Cap 3:98-128

86. Tamaki S, Bui VN, Ngo LH, Ogawa H, Imai K (2014) Virucidal effect of acidic electrolyzed water and neutral electrolyzed water on avian influenza viruses Arch Virol 159(3):405-412

87. Zhao Y, Xin H, Zhao D, Zheng W, Tian W, Ma H et al (2014) Free chlorine loss during spraying of membraneless acidic electrolyzed water and its antimicrobial effect on airborne bacteria from poultry house. Ann Agric Environ Med 21(2):249-255

88. Ahn D-G, Shin H-J, Kim M-H, Lee S, Kim H-S, Myoung J et al (2020) Current status of epidemiology, diagnosis, therapeutics, and vaccines for novel coronavirus disease 2019 (COVID-19). J Microbiol Biotechnol 30(3):313-324

89. Duffy S (2018) Why are RNA virus mutation rates so damn high? PLoS Bio 16(8):e3000003

90. Khurshid Z, Asiri FYI, Al Wadaani H (2020) Human saliva: non-invasive fluid for detecting Novel Coronavirus (2019-nCoV). Int J Environ Res Public Health 17(7):2225

91. Sabino-Silva R, Jardim ACG, Siqueira WL (2020) Coronavirus COVID-19 impacts to dentistry and potential salivary diagnosis. Clin Oral Investig 24(4): 1619-1621

92. Sharma S, Kumar V, Chawla A, Logani A (2020) Rapid detection of SARSCoV-2 in saliva: Can an endodontist take the lead in point-of-care COVID-19 testing? Int Endod J 53(7):1017-1019

93. To KK-W, Tsang OT-Y, Yip CC-Y, Chan K-H, Wu T-C, Chan JM-C et al (2020) Consistent detection of 2019 novel coronavirus in saliva. Clin Infect Dis. https://doi.org/10.1093/cid/ciaa149

94. Ogden G, Bahrami M, Sivarajasingam V, Phillips G (1997) Dental students' knowledge and compliance in cross infection control procedures at a UK dental hospital. Oral Dis 3(1):25-30

\section{Publisher's Note}

Springer Nature remains neutral with regard to jurisdictional claims in published maps and institutional affiliations.

\section{Submit your manuscript to a SpringerOpen ${ }^{\circ}$ journal and benefit from:}

- Convenient online submission

- Rigorous peer review

- Open access: articles freely available online

- High visibility within the field

- Retaining the copyright to your article

Submit your next manuscript at $\boldsymbol{\nabla}$ springeropen.com 